\title{
KONDISI HABITAT BULU BABI Tripneustes gratilla (LINNAEUS, 1758) DI TELUK CENDERAWASIH
}

\author{
Abdul Hamid A. Toha ${ }^{1,2,{ }^{*} \text {, Sutiman B. Sumitro², Luchman Hakim², Widodo² }}$ \\ 1 Jurusan Perikanan, Fakultas Peternakan, Perikanan dan Ilmu Kelautan, Universitas Negeri Papua, Manokwari, Papua Barat, \\ 2Jurusan Biologi, FMIPA Universitas Brawijaya. \\ *Corresponding author: E-mail: hamid.toha@gmail.com
}

\begin{abstract}
The primary goal of this research was determine physical and chemistry conditions of habitat of Tripneustes gratilla at Cenderawasih Bay waters. Sites of research were Manokwari, Wasior, Biak, Yapen and Nabire. Habitat of T. gratilla was observed directly with determine of temperature, salinity, velocity of current, $\mathrm{pH}$, and dissolved oxygen by using thermometer, saline refractometer, $\mathrm{pH}-\mathrm{meter}$

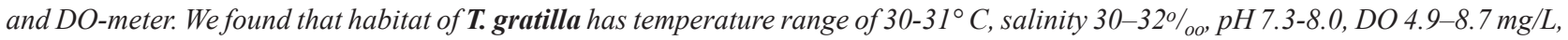
wave frequency $0.32-0.72 \mathrm{~Hz}$, and current velocity $0.06-0.1 \mathrm{~m} / \mathrm{sec}$. Statistic test showed that T. gratilla were impacted by DO about $80 \%$ and wave frequency with 66\%. In general, habitat of $\boldsymbol{T}$. gratilla in Cenderawasih Bay were in good condition and supporting growth, develop and survival of T. gratilla.
\end{abstract}

Keywords: T. gratilla, temperature, salinity, pH, DO, wave, current velocity, Cenderawasih Bay

\section{PENGANTAR}

Teluk Cenderawasih merupakan kawasan perairan yang kaya akan biota laut. Teluk ini memiliki paling sedikit 5.000 spesies karang, lebih dari 1.000 spesies ikan dan terdapat berbagai jenis moluska, penyu, mamalia laut dan biota laut lain (Allen \& Erdmann, 2009, Ministry of Forestry, 2010). Perairan Cenderawasih juga sering menjadi wilayah temuan spesies baru pada beberapa tahun terakhir. Di perairan ini ditemukan 10 spesies baru dalam kurun 2006-2010 (Alonso dkk., 2011).

Tripneustes gratilla (Linneaus 1758) adalah bulu babi perairan dangkal yang tersebar luas di Indo-Pasifik tropis (Lawrence \& Agatsuma, 2001, Lessios, dkk., 2003) termasuk di Perairan Teluk Cenderawasih (Toha dkk, 2009). Kelangsungan hidup dan perkembangan biak T. gratilla sangat ditentukan oleh kondisi perairan habitat bulu babi tersebut. Suhu, salinitas, $\mathrm{pH}$, kejenuhan $p \mathrm{CO}_{2}$ dan $\mathrm{CaCO}_{3}$, arus, dan gelombang adalah di antara faktor-faktor lingkungan tersebut. Beberapa penelitian tentang kondisi perairan pernah dilakukan, di antaranya adalah perubahan iklim pada pengasaman laut dan perkembangan invertebrata (Byrne, 2010), pemanasan laut akibat kenaikan suhu (Stachowicz, dkk., 2002), pemanasan terhadap fenologi pelagis laut (Edwards \& Richardson, 2004), dan tanggapan larva bulu babi pada penurunan $\mathrm{pH}$ air laut (Clark, dkk., 2009).

Penelitian kondisi oseanografi di Teluk Cenderawasih pernah dilakukan oleh beberapa ahli termasuk Edward \& Marasabessy (2003). Beberapa penelitian di Teluk
Cenderawasih dengan parameter khusus juga pernah dilakukan, misalnya suhu (EBM Factsheet, 2010) dan salinitas (Zenk, dkk., 2005). Meskipun demikian penelitian kondisi oseanografi dan habitat yang terkait langsung dengan T. gratilla belum pernah dilakukan selama ini. Penelitian ini bertujuan menentukan suhu, salinitas, oksigen terlarut (DO), arus, frekuensi gelombang dan $\mathrm{pH}$ pada perairan habitat T. gratilla di Perairan Teluk Cenderawasih.

\section{BAHAN DAN CARA KERJA}

Penelitian dilakukan pada beberapa pantai berbeda di Perairan Manokwari, Dusner (Wasior), Biak, Yapen dan Nabire. Penelitian berlangsung dalam kurun waktu April-Oktober 2009. Khusus di Manokwari dilakukan pengamatan pada Perairan Rendani dan Saubeba.

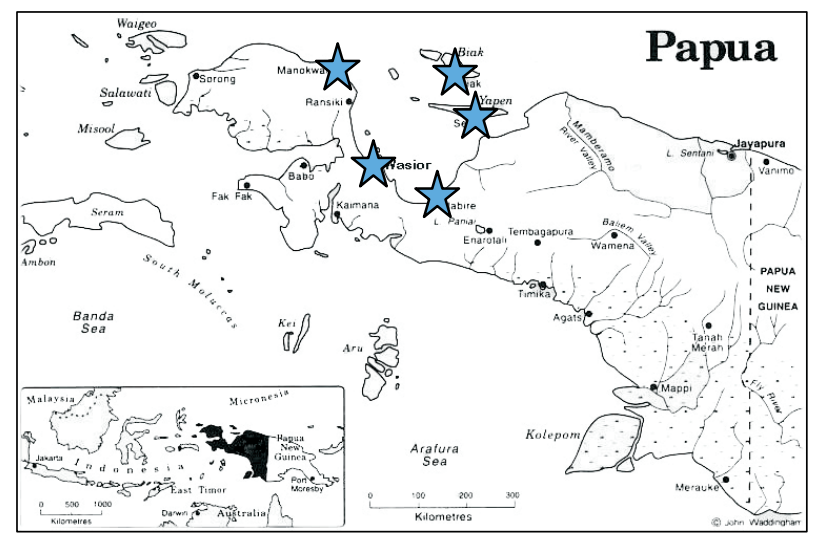

Gambar 1. Lokasi penelitian, Manokwari, Wasior, Biak, Serui, dan Nabire 
Lokasi dipilih secara purposive berdasarkan keberadaan T. gratilla. Habitat T. gratilla diamati langsung secara visual. Data perairan yang diukur meliputi suhu, salinitas, kecepatan arus, $\mathrm{pH}$, oksigen terlarut dan frekuensi gelombang. Pengukuran parameter perairan tersebut dilakukan secara in situ menggunakan alat salinorefratometer, DO-meter, pH meter, dan lain-lain. Data selanjutnya dianalisis secara deskriptif dan disajikan dalam bentuk tabulasi gambar dan grafik. Uji statistik juga dilakukan untuk mengetahui pengaruh setiap parameter oseanografi yang diukur.

\section{HASIL}

T. gratilla mendiami beragam habitat di lokasi penelitian. Beberapa T. gratilla mendiami habitat yang
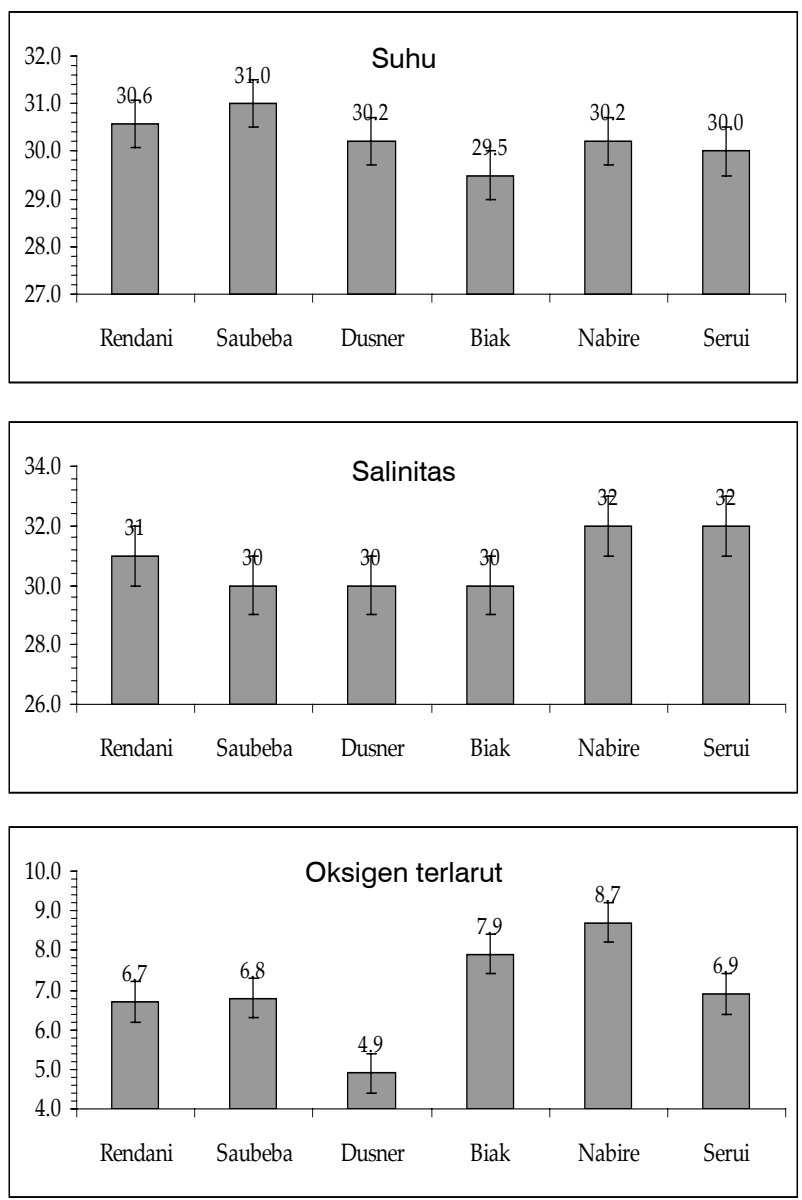

memiliki padang lamun, alga, dan sebagian lain mendiami terumbu karang. Beberapa jenis sedimen T. gratilla adalah pasir, lumpur, dan pecahan karang. Spesies umumnya ditemukan pada pesisir pantai dengan kedalaman bervariasi 0,3 sampai 20 meter.

Hasil pengukuran suhu, salinitas, DO, kecepatan arus, frekuensi gelombang dan $\mathrm{pH}$ perairan habitat $T$. gratilla disajikan pada Gambar 2.

Kisaran suhu antara $30^{\circ} \mathrm{C}-31^{\circ} \mathrm{C}$, salinitas $30 \%{ }^{\circ}-$ $32 \%$ oo, pH 7,3-8, dan DO antara 4,9-8,7 mg/L. Ada kesamaan yang cukup signifikan pada seluruh lokasi penelitian.

Uji statistik menunjukkan keberadaan $T$. gratilla pada suatu habitat dipengaruhi oleh faktor lingkungan seperti ditunjukkan pada Tabel 1.
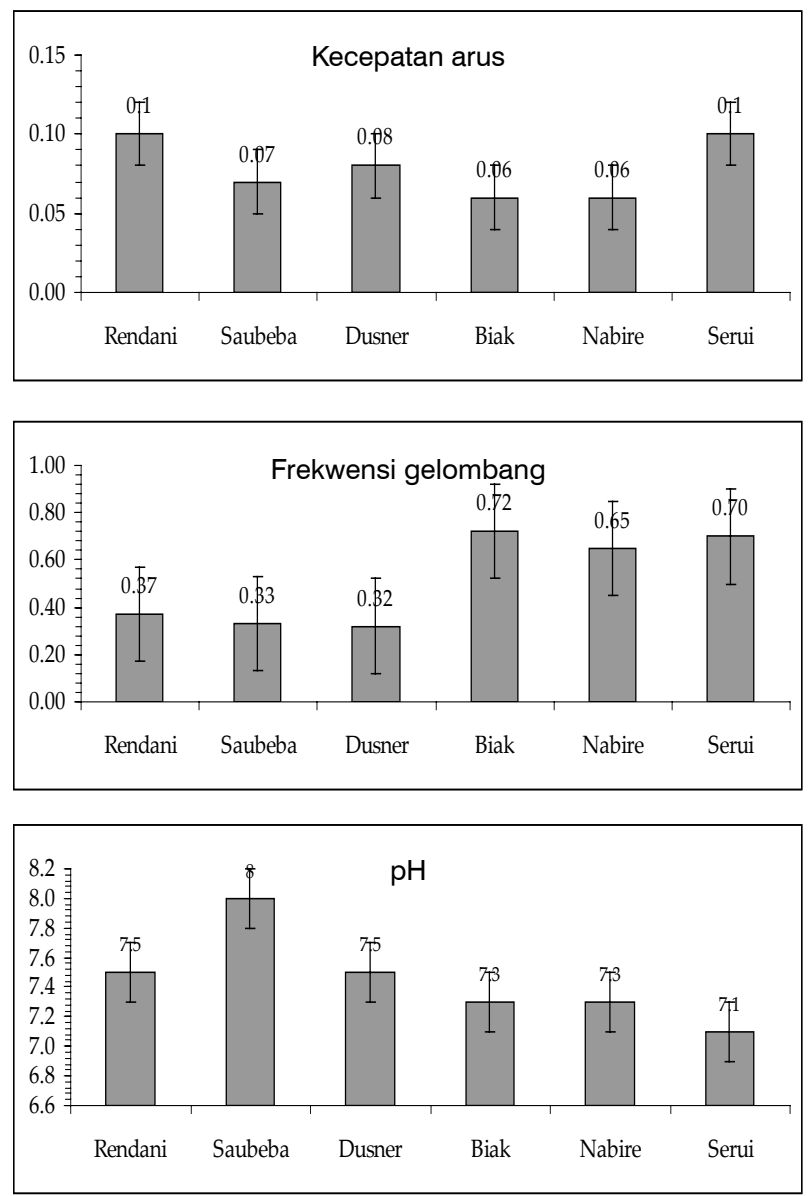

Gambar 2. Hasil pengukuran parameter fisik dan kimia habitat $T$. gratilla Teluk Cenderawasih. Hasil pengukuran terdiri atas suhu, salinitas, oksigen terlarut, kecepatan arus, frekuensi gelombang dan $\mathrm{pH}$. 
Tabel 1. Uji Korelasi Pengaruh Parameter Lingkungan

\begin{tabular}{llcc}
\hline \multirow{2}{*}{ No } & \multirow{2}{*}{ Parameter } & \multicolumn{2}{c}{ Uji Korelasi } \\
\cline { 3 - 4 } & & $\mathbf{R}^{\mathbf{2}}$ & $\mathbf{R}$ \\
\hline 1 & Arus & 0.1182 & 0.344 \\
2 & pH & 0.0173 & 0.132 \\
3 & Salinitas & 0.2546 & 0.505 \\
4 & DO & 0.6453 & 0.803 \\
5 & Suhu & 0.0001 & 0.010 \\
6 & Gelombang & 0.4422 & 0.665 \\
\hline
\end{tabular}

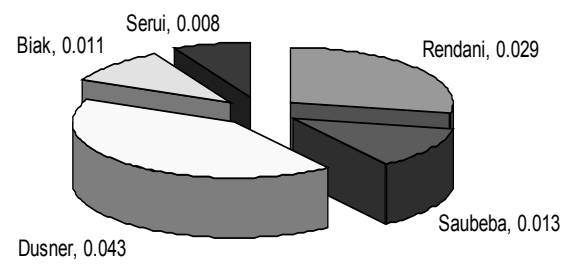

Gambar 3. Kepadatan T. gratilla (individu $/ \mathrm{m}^{2}$ ) pada lokasi penelitian

Kondisi di atas mempengaruhi kepadatan T. gratilla seluruh lokasi penelitian seperti ditunjukkan pada Gambar 3.

\section{PEMBAHASAN}

T. gratilla ditemukan pada kedalaman sampai $20 \mathrm{~m}$. Habitat $T$. gratilla di padang lamun, alga, dan karang dengan dasar perairan berpasir, berlumpur atau substrat yang memiliki pecahan karang. Hal ini seperti temuan beberapa ahli. Radjab (2004) menemukan T. gratilla pada habitat berpasir atau pasir berlumpur yang ditumbuhi lamun pada kedalaman 0,5-20 m. Lawrence \& Agatsuma (2007) menemukan $T$. gratilla di perairan sangat dangkal hingga kedalaman $75 \mathrm{~m}$. Spesies ini mendiami berbagai jenis habitat termasuk padang lamun (Sammarco, 1987; Sumitro, dkk., 1992; Aziz, 1994; Susetiono, 2004), alga dan mikroalga (Ogden, dkk., 1989), pasir dengan pecahan karang, dan rataan terumbu (Lawrence \& Agatsuma, 2007).

Suhu habitat $T$. gratilla bervariasi menurut ekosistem setiap lokasi penelitian. Meskipun demikian kisaran suhu antar lokasi tergolong kecil. Pada penelitian ini suhu habitat T. gratilla antara $29,5-31^{\circ} \mathrm{C}$ (Gambar 2, Suhu). Kisaran suhu ini mendukung pertumbuhan T. gratilla. Baku mutu parameter suhu alami pada koral, mangrove, dan lamun yang menjadi habitat $T$. gratilla berturut-turut $28-20^{\circ} \mathrm{C}$, $28-32^{\circ} \mathrm{C}$, dan $28-30^{\circ} \mathrm{C}$ (Kantor MenLH, 2004). Suhu yang baik bagi pertumbuhan hewan bentik adalah $25-33^{\circ} \mathrm{C}$.

Hasil ini mirip temuan CI-Indonesia, TNC dan WWF di kawasan Kepala Burung Papua termasuk Teluk Cenderawasih. Rata-rata suhu perairan Teluk Cenderawasih dalam kurun waktu 2005-2008 adalah 29,5 $5^{\circ} \mathrm{C}$ dengan kisaran antara 24,94-31,59 ${ }^{\circ} \mathrm{C}$ (EBM Factsheet, 2010). Suhu habitat $T$. gratilla di Teluk Cenderawasih ini lebih hangat dengan di Pulau Bonin, berkisar 23.6-26.8 $\mathrm{C}$ (Shigei, 1970), di Teluk Seto, Jepang, antara $14-28^{\circ} \mathrm{C}$, dan di New South Wales, Australia, antara $20-26^{\circ} \mathrm{C}$ (Vaïtilingon dkk, 2005). Hangatnya perairan lokasi penelitian kemungkinan karena Teluk Cenderawasih memiliki morfologi semi tertutup. Selain itu, rendahnya suhu perairan lokasi terakhir disebabkan berada di daerah subtropis dan kemungkinan adanya pergerakan massa air yang lebih dingin dari bawah ke permukaan sehingga menyebabkan suhu air laut di permukaan relatif rendah.

Menurut Mos dkk. (2012) suhu adalah satu dari beberapa faktor paling penting yang mempengaruhi pertumbuhan bulu babi. Suhu adalah faktor lingkungan utama yang mengendalikan fisiologi, fenologi, durasi larva planktonik dan biogeografi invertebrata laut (O'Connor dkk, 2007; Bryne dkk, 2010). Suhu perairan dapat mempengaruhi proses metabolisme dan siklus reproduksi bulu babi. Suhu sangat berpengaruh terhadap perkembangan singkat periode planktonik bulu babi yang mengakibatkan penurunan tekanan predasi dan juga mengubah hubungan antar populasi (O'Connor dkk, 2007; Byrne dkk, 2010).

Salinitas Perairan Indonesia umumnya berkisar antara $32 \%{ }_{00}-37 \%{ }_{00}$ (Romimohtarto \& Thayib, 1982). Pada penelitian ini salinitas habitat $T$. gratilla berkisar $31 \%$ $32 \%$ (Gambar 2, Salinitas). Hasil ini mirip dengan temuan Edward \& Marasabessy (2003) yang melaporkan salinitas berkisar $31 \% 00-34,5 \%$ o pada kedalaman $0-50 \mathrm{~m}$. Kondisi ini mendukung kehidupan T. gratilla. Hal ini sesuai baku mutu parameter salinitas air laut masing-masing untuk habitat koral 33-34\% 00 , mangrove sampai dengan 34\% 00 , dan lamun 33-34\% ${ }_{00}$ (Kantor MenLH, 2004). Menurut Anonim (1985) baku mutu air laut menetapkan nilai ambang batas (NAB) salinitas alami sebesar $\pm 10 \%$ variasi alami untuk kehidupan biota laut, dan antara 18,0-32,0\% ${ }_{00} \pm 10 \%$ variasi alami untuk budi daya biota laut.

Hasil penelitian ini juga menunjukkan variasi salinitas antar lokasi perairan relatif kecil. Kecilnya variasi karena tidak ada sungai yang bermuara ke lokasi penelitian dan sirkulasi massa air relatif lancar di lokasi penelitian. Selain itu, kecilnya variasi karena morfologi Teluk Cenderawasih yang relatif tertutup. EBM Factsheet (2010) menyatakan 
bahwa Teluk Cenderawasih dapat ditinjau sebagai danau air laut besar, dengan lingkungan yang stabil yang terpisah dan berbeda dengan perairan luar teluk karena memiliki beberapa keunikan termasuk secara osenografi. Menurut Zenk dkk. (2005) Teluk Cenderawasih merupakan pusat utama perairan dengan salinitas rendah di kawasan cekung Papua bagian utara.

Dalam masa pertumbuhan, salinitas merupakan faktor yang sangat penting, dengan kata lain variasi salinitas dapat mempengaruhi organisme laut, efek perubahan salinitas dapat mempengaruhi derajat kelangsungan hidup dan pertumbuhan organisme. Bulu babi tergolong hewan stenohalin (Roller \& Stickle 1993) dan fluktuasi salinitas dapat memiliki pengaruh berbeda pada pertumbuhan dan kelangsungan hidup larva dan juvenil bulu babi (Drouin dkk. 1985). Perubahan salinitas juga akan mengubah parameter laut lainnya seperti DO sehingga kestabilan lingkungan akan terganggu seiring dengan perubahan salinitas.

Konsentrasi oksigen terlarut pada penelitian ini berkisar 4,9 mg/L (Wasior)-8,7 mg/L (Nabire) (Gambar 2, Oksigen terlarut). Nilai DO rendah di Wasior karena posisi perairan agak terlindung masing-masing dari arus dan gelombang kuat sehingga sirkulasi massa air relatif kurang. Kejadian sebaliknya terjadi pada lokasi lain. Meskipun demikian secara keseluruhan kisaran DO seluruh lokasi penelitian masih berada dalam kisaran yang cukup baik. Baku mutu oksigen terlarut suatu perairan adalah $>4 \mathrm{mg} / \mathrm{L}$ (Kantor MenLH, 2004). Hasil ini berbeda dengan temuan Edward \& Marasabessy (2003) yang menemukan kisaran oksigen terlarut antara 2,6-4,6 ml/L pada kedalaman 0-50 m.

Oksigen terlarut sangat vital untuk siklus kehidupan dalam air. Oksigen sangat esensial untuk menjaga organisme tetap hidup, proses reproduksi, dan untuk perkembangan populasi. Konsentrasi oksigen terlarut yang dapat ditolerir biota perairan untuk berbagai kebutuhan hidup berbeda-beda namun tetap berada dalam standar baku mutu lingkungan. Air yang mengandung konsentrasi oksigen rendah akan mempengaruhi kesehatan organisme karena organisme akan mudah terserang parasit dan penyakit, dan konsentrasi oksigen terlarut di bawah baku mutu menyebabkan nafsu makan seperti ikan tanpa terkecuali $T$. gratilla menurun dan tidak berkembang dengan baik.

Sirkulasi massa air pada habitat $T$. gratilla kurang dari $0,1 \mathrm{~m} /$ det atau kisaran 0,06-0,1 m/det (Gambar 2, Kecepatan Arus) sedangkan frekuensi gelombang berkisar 0,32 hingga $0,72 \mathrm{~Hz}$ (Gambar 2, Frekuensi Gelombang). Kecepatan arus mirip seperti di padang lamun Pulau Hatta (bagian tenggara, timur, utara dan barat). Kecepatan arus laut daerah ini berkisar 0,05-0,12 m/det (Dobo, 2009).
Arus dan gelombang berpengaruh langsung terhadap distribusi spesies $T$. gratilla terutama pada masa larva yang sifatnya planktonik dan gerakannya mengikuti gerakan arus dan gelombang sampai menemukan habitat yang sesuai. Selain itu gelombang dan arus mempengaruhi daya tahan T. gratilla melalui transportasi nutrien-nutrien penting di samping lamun.

T. gratilla pada masa larva bersifat planktonik, mudah terbawa arus dan gelombang dari satu tempat ke tempat lain. Menurut Juinio-Meñez dkk. (1998) fase larva T. gratilla berkisar antara 45 sampai 52 hari mendukung penyebarannya secara luas. Larva pelagis meningkatkan penyebaran antar lokasi yang berjauhan dan mengurangi penyimpangan genetik (Rocha dkk, 2007). Ada indikasi bahwa perilaku aktif larva, proses oseanografi lokal, dan waktu pemijahan dengan gelombang dan arus merupakan faktor-faktor biologi dan fisik yang mempengaruhi penyebaran larva melalui peningkatan retensi lokal (Cowen, 2002; Cowen dkk, 2006). Akibatnya, dapat dimengerti bahwa beberapa spesies memiliki keterkaitan meskipun populasi berbeda secara demografi (Leis, 2002; Swearer dkk, 2002).

pH perairan lokasi penelitian antara 7,1-8,0 (Gambar $2, \mathrm{pH})$. Seperti parameter lain, kisaran $\mathrm{pH}$ ini relatif tidak terlalu bervariasi dan dapat mendukung kelangsungan hidup T. gratilla. Perairan ideal bagi bulu babi memiliki $\mathrm{pH}$ air berkisar 6,5-8,5. Kisaran $\mathrm{pH}$ masih sesuai dengan baku mutu $\mathrm{pH}$ air laut antara 7-8,5 (Kantor MenLH, 2004).

Havenhand dkk (2008) menunjukkan bahwa bila pH perairan penurunan $\mathrm{pH}$ normal dari 8,1 ke 7,7, menyebabkan penurunan kemampuan bulu babi berkembang biak sebesar 25 persen, karena sperma berenang lebih lambat dan bergerak kurang efektif. Jika pembuahan berhasil, perkembangan larva bulu babi terganggu sampai hanya 75 persen dari telur yang sehat. Sementara Clark dkk. (2009) menunjukkan bahwa penurunan $\mathrm{pH}$, di bawah 7,0, menyebabkan penurunan kelangsungan hidup dan ukuran larva, meskipun morfologi eksternal (bentuk) larva tidak terpengaruh.

Asidifikasi laut, fenomena penurunan $\mathrm{pH}$ laut karena serapan $\mathrm{CO}_{2}$ antropogenik, telah diidentifikasi sebagai konsekuensi penting meningkatnya emisi $\mathrm{CO}_{2}$ seluruh dunia (Feely dkk, 2004; Orr dkk, 2005; Fabry dkk, 2008). Studi menunjukkan bahwa asidifikasi mempunyai pengaruh negatif pada fertilisasi (Kurihara, 2008; Havenhand dkk., 2008). Serapan $\mathrm{CO}_{2}$ ini menurunkan $\mathrm{pH}$ laut melalui konversi $\mathrm{CO}_{2}$ terlarut ke dalam asam karbonat $\left(\mathrm{H}_{2} \mathrm{CO}_{3}\right)$ yang selanjutnya terurai menjadi bikarbonat $\left(\mathrm{HCO}_{3}{ }^{-}\right)$, karbonat $\left(\mathrm{CO}_{3}{ }^{2-}\right)$ dan ion hidrogen $\left(\mathrm{H}^{+}\right)$(Clark dkk., 2009). Lebih lanjut asidifikasi laut adalah ancaman utama pengapuran invertebrata laut 
karena menurunnya kesediaan ion karbonat yang dibutuhkan selama skeletogenesis (Widdicome \& Spicer, 2008; Doney dkk, 2009; Christensen dkk, 2011).

Keberadaan $T$. gratilla pada suatu habitat ditentukan oleh berbagai faktor oseanografi baik fisika, kimia dan biologi bahkan substrat perairan. Uji statistik menunjukkan hubungan korelasi kehadiran $T$. gratilla pada suatu habitat dipengaruhi oleh faktor lingkungan. Akan tetapi dari sekian banyak faktor lingkungan terdapat dua parameter yang paling berpengaruh yaitu DO dan frekuensi gelombang yaitu masing-masing $80 \%$ dan $66 \%$ (Tabel 1).

Tingginya pengaruh DO dan frekuensi gelombang berkaitan langsung dengan kelangsungan hidup $T$. gratilla. Gelombang dapat memberikan pasokan air segar, oksigen, plankton dan membantu menghalangi terjadinya pengendapan pada suatu habitat. Frekuensi gelombang (bersama arus) dapat mempengaruhi daya tahan organisme melalui transportasi nutrien dan distribusi $T$. gratilla pada habitat yang sesuai untuk menetap. Sedangkan oksigen terlarut sangat penting terutama dalam proses respirasi $T$. gratilla.

Fertilisasi T. gratilla dan echinoid lain tahan terhadap tekanan perubahan iklim (Byrne dkk, 2010; Byrne, 2010; Byrne dkk, 2010b). Meskipun demikian T. gratilla dapat bertahan untuk jangka waktu lama apabila ditunjang oleh kondisi habitat dengan berbagai faktor yang mempengaruhinya sehingga keberadaan dan kepadatannya tetap stabil bahkan sifat dan karakter fenotip seperti warna ditentukan oleh kondisi lingkungannya.

Kepadatan T. gratilla bervariasi antar lokasi namun cukup kecil. Pada penelitian ini kepadatan T. gratilla berkisar 0,01 sampai 0,043 individu/m² (Gambar 3). Kepadatan ini lebih tinggi dari T. gratilla di Perairan Padaido, Biak-Papua (0,003-0,02 individu/m²) (Radjab, 2004) dan lebih rendah dari kepadatan T. gratilla di Pulau Hatta (Maluku), 4,22-5,89 individu/m² (Dobo, 2009) dan di Bali 1-60 individu/50 $\mathrm{m}^{2}$. Di Perairan Pulau Osi kepadatan T. gratilla adalah $0,754 \pm 0,152 \mathrm{individu} / \mathrm{m}^{2}$ (Syam dkk, 2002), di Perairan Nusa Dua, Bali 0,278 individu $/ \mathrm{m}^{2}$ (Darsono \& Sukarno, 1993), di Banda Neira 2,83 individu/ $\mathrm{m}^{2}$ (Andamari dkk, 1994), dan di Kema 0,84 individu/ $\mathrm{m}^{2}$ (Supono \& Arbi, 2010).

T. gratilla berada dalam kepadatan rendah karena kurangnya kemampuan bersaing dalam menempati habitat. Kepadatan tinggi $T$. gratilla umumnya berkaitan dengan perkembangbiakan. Selain itu kepadatan tinggi juga berkaitan dengan ketersediaan makanan yang cukup dan kondisi substrat yang didominasi oleh sedimen berpasir yang lebih disukai oleh bulu babi jenis ini.
Dari pembahasan di atas dapatlah dikatakan bahwa kondisi perairan di Teluk Cenderawasih masih berada dalam kisaran normal dan dapat mendukung kelangsungan hidup $T$. gratilla. Pada umumnya $T$. gratilla ditemukan di padang lamun bersedimen pasir dan pasir berlumpur. Suhu habitat $T$. gratilla berkisar antara $30-31^{\circ} \mathrm{C}$. Suhu perairan tertinggi ditemukan di Perairan Saubeba, $31^{\circ} \mathrm{C}$, kemudian Rendani $30,6^{\circ} \mathrm{C}$, Dusner dan Nabire, $30,2^{\circ} \mathrm{C}$, Serui, $30,0^{\circ}$ C, dan Biak $29,5^{\circ}$ C. Salinitas habitat T. gratilla berkisar 30-32\% dengan salinitas tertinggi di Perairan Serui dan Nabire, $32 \%$ oo, disusul Rendani, $31 \%$ oo dan terendah di Saubeba, Dusner, dan Biak, $30 \%$ oo Kecepatan arus pada lokasi penelitian berkisar 0,1-0,06 m/det. Kecepatan arus tertinggi di Perairan Serui dan Rendani 0,1 m/detik, disusul Perairan Dusner 0,08 m/det dan Saubeba 0,7 m/det serta paling rendah di Perairan Biak dan Nabire masing-masing $0,06 \mathrm{~m} / \mathrm{det}$. Frekuensi gelombang antara $0,72-0,32 \mathrm{~Hz}$ dengan frekuensi gelombang tertinggi habitat di Biak 0,72 $\mathrm{Hz}$, lalu Serui 0,7 Hz, Nabire 0,65 Hz, Rendani 0,37 Hz, Saubeba $0,33 \mathrm{~Hz}$, dan Dusner 0,32. $\mathrm{pH}$ habitat $T$. gratilla berkisar 7,3-8 dan pH tertinggi di Perairan Saubeba 8, disusul Rendani dan Dusner 7,5, Biak dan Nabire 7,3 dan paling rendah di Serui 7,1. DO habitat $T$. gratilla di Teluk Cenderawasih berkisar 4,9-8,7 mg/L. DO tertinggi ditemukan di Nabire 8,7, disusul Biak 7,9, Serui 6,9, Saubeba 6,8, Rendani 6,7 dan paling rendah di Dusner 4,9. Uji statistik menunjukkan kehadiran T. gratilla dipengaruhi oleh DO $80 \%$ dan frekuensi gelombang perairan $66 \%$.

\section{TERIMA KASIH}

Kami menyampaikan terima kasih kepada Lembaga Penelitian Universitas Negeri Papua. Kami juga menyampaikan terima kasih kepada Robi Binur, S.Si, M.Si dan Suhaemi, S.Ik., M.Si atas pengambilan data di lapangan. Penelitian ini merupakan bagian dari Penelitian Strategis Nasional yang didanai oleh DIPA UNIPA sesuai Surat Perjanjian Penyelenggaraan Hibah PSN Nomor: 235/H42/KU/2009 kepada AHAT.

\section{KEPUSTAKAAN}

Allen, G.R., Erdmann, M.V. 2009. Reef fishes of the Bird's Head Peninsula, West Papua, Indonesia. Check List 5(3): 587-628.

Alonso, L.E., Deichmann, J.L., McKenna, S.A., Naskrecki, P., dan Richards, S.J. (Editors), 2011. Biodiversity Exploration for Conservation - The First 20 Years of the Rapid Assessment Program. Conservation International, Arlington, VA, USA, 316 pp. 
Andamari, R., Zubaidi, T., dan Subagyo, 1994. Beberapa Aspek Biologi Bulu Babi Tripneustes spp. Di Pulau Neira, Kepulauan Banda. Jurnal Penelitian Perikanan Laut, 94: 23-34.

Anonim, 1985. Baku mutu lingkungan hidup dan pengendalian pencemaran lingkungan. Laporan khusus: Asisten I Menteri Negara Kependudukan dan Lingkungan Hidup. Jakarta.

Aziz, A. 1994. Aktivitas grazing bulu babi jenis Tripneustes gratilla pada padang lamun di pantai Lombok Selatan. Dalam: W. Kiswara, M.K. Mosa, \& M. Hutomo (eds.). Struktur komunitas biologi padang lamun di pantai selatan Lombok dan kondisi lingkungannya. P3O-LIPI. Jakarta hal 64-70.

Byrne, M. 2010. Impact of climate change stressors on marine invertebrate life histories with a focus on the Mollusca and Echinodermata. In: Yu J, Henderson- Sellers A, eds. Climate alert: Climate change monitoring and strategy. Sydney: University of Sydney Press. pp 142-185.

Byrne, M., Selvakumaraswamy, P., Ho, MA., Woolsey, E., dan Nguyen, HD. 2010a. Sea urchin development in a global change hot spot, potential for southerly migration of thermotolerant propagules. Deep Sea Res II

Byrne, M., Soars, N., Selvakumaraswamy, P., Dworjanyn, S.A., dan Davis, A.R. 2010b. Sea urchin fertilisation in a warm, acidified and high $\mathrm{pCO}_{2}$ ocean across a range of sperm densities. Mar Env Res, 69: 234-239.

Christensen, A.B., Nguyen, H.D., dan Byrne, M. 2011. Thermotolerance and the effects of hypercapnia on the metabolic rate of the ophiuroid Ophionereis schayeri: inferences for survivorship in a changing ocean. Journal of Experimental Marine Biology and Ecology, DOI: 1001016/ j.jembe.2011.04.002

Clark, D., Lamare, M., dan Barker, M. 2009. Response of sea urchin pluteus larvae (Echinodermata: Echinoidea) to reduced seawater $\mathrm{pH}$ : a comparison among a tropical, temperate, and a polar species. Mar Biol, 156: 1125-1137. DOI 10.1007/s00227-009-1155-8.

Cowen, R.K. 2002. Larval dispersal and retention and consequences for population connectivity. Pp. 149-170 in Coral Reef Fishes. Dynamics and Diversity in a Complex Ecosystem. P.F. Sale, ed., Academic Press, San Diego, CA.

Cowen, R.K., Paris, C.B., dan Srinivasan, A. 2006. Scaling of population connectivity in marine populations. Science 311 : 522-527.

Darsono, P., dan Sukarno, 1993. Beberapa aspek biologi bulubabi Tripneustes gratilla (Linnaeus) di Nusa Dua, Bali. Osenologi di Indonesia, 26: 13-25.

Dobo, J. 2009. Tipologi komunitas lamun kaitannya dengan populasi bulu babi di Pulau Hatta Kepulauan Banda, Maluku. Tesis Sekolah Pascasarjana Institut Pertanian Bogor, Bogor. Tidak diterbitkan.

Doney, S.C., Fabry, V.J., Feely, R.A., dan Kleypas, J.A. 2009. Ocean acidification: the other $\mathrm{CO}_{2}$ problem. Ann Rev Mar Sci, 1: 169-192.
Drouin, G., Himmelman, J.H., dan Beland, P. 1985. Impact of tidal salinity fluctuations on echinoderm and mollusc populations. Canadian Journal of Zoology, 63: 1377-1387.

EBM Factsheet, 2010. Sea surface temperature monitoring in the Bird's Head Seascape. Ecosystem Based Management. Bird's Head Seascape, Papua. Nature.or.id/ed/wp/-content/ uploads/2012/06/EBM-Factsheet-2010-SST-English.pdf.

Edward, Marasabessy, M.D. 2003. Kondisi oseanografi Teluk Cenderawasih, Irian Jaya ditinjau dari kepentingan perikanan. Marina Chimica Acta, 4(1): 1-4.

Edwards, M., dan Richardson, A.J. 2004. Impact of climate change on marine pelagic phenology and trophic mismatch. Nature, 430, 881-884.

Fabry, V.J., Seibel, B.A., Feely, R.A., dan Orr, J.C. 2008. Impacts of ocean acidification on marine fauna and ecosystem processes. ICES J Mar Sci, 65:414-432. doi:10.1093/ icesjms/fsn048

Feely, R.A., Sabine, C.L., Lee, K., Berelson, W., Kleypas, J., Fabry, V.J., dan Millero, F.J. 2004. Impact of anthropogenic $\mathrm{CO}_{2}$ on the $\mathrm{CaCO}_{3}$ system in the oceans. Science, 305: 362-366.

Havenhand, J.N., Buttler, F.R., Thorndyke, M.C., dan Williamson, J.E. 2008. Near-future levels of ocean acidification reduce fertilization success in a sea urchin. Current Biology, 18(5): 651-652.

Juinio-Meñez, M.A., Macawaris, N., dan Bangi, H. 1998. Community-based sea urchin (Tirpneustes gratilla) growout culture as a resource management tool. Can. Spec. Pub. of Fish and Aqua Sci. 125: 393-399.

Kantor MenLH. 2004. Keputusan Menteri Negara Lingkungan Hidup no. 51/MenLH/2004 tentang Baku Mutu Air Laut. Kantor Menteri Lingkungan Hidup. Jakarta.

Kurihara, H. 2008. Effect of $\mathrm{CO}_{2}$-driven ocean acidification on the early development stages of invertebrates. Marine Ecology Progress Series, 275: 275-284.

Lawrence, J.J., dan Agatsuma, Y. 2001. The ecology of Tripneustes. In: Lawrence, J.W. (Ed). Edible sea urchin: Biologi and Ecology Developments in Aquaculture and Fisheries Science, 32. Elsevier.

Lawrence, J.M., dan Agatsuma, Y. 2007. Ecology of Tripneustes. In: Lawrence JM, ed. The biology and ecology of edible urchins, Elsevier Science, Amsterdam. pp 499-520.

Leis, J.M. 2002. Pacific coral-reef Fishes: the implications of behavior and ecology of larvae for biodiversity and conservation, and a reassessment of the open population paradigm. Env Biol Fishes, 65:199-208 Lessios HA, Robertson.

Lessios, H.A., Kane, J., dan Robertson, DR. 2003. Phylogeography of the pantropical Sea Urchin Tripneustes: Constrasting patterns of Population Structure Between Oceans. Evolution, 57 (9): 2026-2036.

Ministry of Forestry and Ministry of Marine Affairs \& Fisheries. 2010. Gap Analysis of Protected Areas Ecological Representativeness in Indonesia, Jakarta Ministry of 
Forestry and Ministry of Affairs \& Fisheries (Table 2. p. 22).

Mos, B., Cowden, K.L., dan Dworjanyn, S.A. 2012. Potential for the commercial culture of the tropical sea urchin Tripneustes gratilla in Australia. RIRDC publication No. 12/052 RIRDC project No. PRJ-006543.

O'Connor, M.I., Bruno, J.F., Gaines, S.D., Halpern, B.S., dan Lester SE. 2007. Temperature control of larval dispersal and the implications for marine ecology, evolution, and conservation. Proc Natl Acad Sci U S A, 104: 12661271.

Ogden, N., Ogden, S.C., Abbot, I.A. 1989. Distribution, abundance, and food of sea urchins on a leeward Hawaiian reef. Bull Mar Sci, 45: 539-549.

Orr, J.C., Fabry, V.J., Aumont, O., Bopp, L., Doney, S.C., Feely, R.A., Gnanadesikan, A, Gruber, N., Ishida, A., Joos, F., Key, R.M., Lindsay, K., Maier-Reimer, E., Matear, R., Monfray, P., Mouchet, A., Najjar, R.G., Plattner, G.K., Rodgers, K.B., Sabine, C.L., Sarmiento, J.L., Schlitzer, R., Slater, R.D., Totterdell, I.J., Weirig, M.F., Yamanaka, Y., dan Yool, A. 2005. Anthropogenic ocean acidification over the twenty-first century and its impact on calcifying organisms. Nature, 437:681-686.

Radjab, A.W. 2004. Sebaran dan kepadatan bulu babi di perairan Kepulauan Padaido, Biak Irian Jaya. Dalam: Setyawan, W.B., Y. Witasari, Z. Arifin, O.S.R. Ongkosongo, S. Biro (eds). Jakarta: Pros. Sem. Laut Nasional III.

Rocha, L.A., Craig, M.T., dan Bowen, B.W. 2007. Phylogeography and the conservation of coral reef Wshes. Coral Reefs. $1-12$.

Roller, R.A., dan Stickle, W.B. 1993. Effect of temperature and salinity acclimation of adults on larval survival, physiology, and early development of Lytechinus variegates (Echinodermata: Echinoidea). Marine Biology 116: 583-591.

Romimohtarto, K., Thayib, S.S. 1982. Kondisi lingkungan dan laut di Indonesia. LON-LIPI. Jakarta: 246.

Sammarco, P.W. 1987. A comparison of some ecological processes on coral reefs of the Carribean and the Great Barrier Reef. Unesco Rep. in Mar.Sci., 46: 127-166.

Shigei, M. 1970. Echinoids of the Bonin Islands. J Fac Sci Univ Tokyo, IV(12): 1-22.

Stachowicz, J.J., Terwin, J.R., Whitlatch, R.B., dan Osman,
R.W. 2002. Lingking climate and biological invasions: ocean warming facilitates noindigenous species invasions. Proceedings of the National Academy of Sciences of the United States of America, 99: 15497-15500.

Sumitro, S.B., Wijarni, U., Pramana, A., Soewondo, A., dan Samino, S. 1992. Inventarisasi jenis, habitat dan tingkah laku hewan bulu babi (Sea Urchin) di Jawa Timur serta usaha pemijahan dan pengembangan teknik kultur embrio. Jurnal Universitas Brawijaya, 4(2): 50-58.

Supono, Arbi UY. 2010. Struktur komunitas ekhinodermata di padang lamun Perairan Kema, Sulawesi Utara. Oseanologi dan Limnologi di Indonesia, 36 (3): 329-342.

Susetiono, 2004. Fauna padang/lamun Tanjung Merah, Selat Lembeh. Pusat Penelitian Oseanografi-LIPI. Jakarta: 106 hal.

Swearer, S.E., Shima, J.S., Hellberg, M.E., Thorrold, S.R., Jones, G.P., Robertson, D.R., Morgan, S.G., Selkoe, K.A., Ruiz, G.M., dan Warner, R.R. 2002. Evidence of selfrecruitment in demersal marine populations. Bull Mar Sci., 70: 251-271

Syam, A.R., Edrus, I.N., dan Andamari, R. 2002. Populasi dan Tingkat Pemanfaatan Bulu Babi (Echinoidea) di Padang Lamun Pulau Osi, Seram Barat, Maluku Tengah. JPPI Edisi Sumber Daya dan Penangkapan, 8 (4): 31-37.

Toha, A.H.A., Binur, R., dan Suhaemi, 2009. Analisis keragaman hayati bulu babi $T$. gratilla dalam upaya konservasi dan menghindari kepunahan organisme model riset biologi. Laporan Penelitian Strategis Nasional Tahun anggaran 2009. Tidak diterbitkan.

Vaïtilingon, D., Rasolofonirina, R., dan Jangoux, M. 2005. Reproductive Cycle of Edible Echinoderms from the Southwestern Indian Ocean. I. Tripneustes gratilla L. (Echinoidea, Echinodermatata). Western Indian Ocean J. Mar. Sci., 4(1): 47-60

Widdicombe, S., dan Spicer, J.I. 2008. Predicting the impact of ocean acidification on benthic biodiversity: what can animal physiology tell us? J Exp Mar Biol Ecol, 366: 187-197.

Zenk, W., Siedler, G., Ishida, A., Holfort, J., Kashino, Y., Kuroda, Y., Miyama, T., dan Müller, T.J. 2005. Pathways and variability of the Antarctic Intermediate water in the western equatorial Pacific Ocean. Progress in Oceanography, 67: 245-281. 